\section{ADDENBROOKE'S HOSPITAL.}

\section{THE NEW SCHEME OF MANAGEMENT.}

THE following circular has been issued to the Governors of Addenbrooke's Hospital by the advisory committee :-You are probably aware that application has been made by the General Court of Governors to the Charity Commissioners to obtain from Parliament a new scheme for the government of the Hospital.

The Act of 1766 gives the management of the Hospital to the Governors at large, who now number about 600 . It is felt that the Institution has outgrown the limits within which this mode of government is efficient, and a Special General Court of Governors has sanctioned an attempt to improve upon it by introducing the principle of a responsible Executive, elected by the Governors, and charged with the administration. This change, it was found, could not be made without fresh legislation, which would cause great expense to the Hospital, if promoted directly by the Governors. If, however, it were promoted by the Charity Commissioners under the powers of "The Charitable Trusts Act, 1853," a new scheme might be obtained without expense ; and this course has accordingly been adopted.

Under the scheme laid before the Charity Commissioners it is proposed that the administration of the hospital shall be conducted and carried on and all its affairs shall be managed by a general committee of 24 elected Governors, eight from residents in the borough, eight from residents in the county, and eight from resident members of the University, who are on the electoral roll, so as to make the committee as far as practicable representative of the borough, county, and University Governors respectively. Certain defined acts and proceedings of the committee are to be subject to confirmation by a General Court of the Governors; and the general committee is to bring up a report of its proceedings at each of the four quarterly courts. The members of the committee to hold office for two years, one half to retire annually.

In a letter dated June 21st, 1902, sent to $\mathrm{Mr}$. Bonnett by Mr. Durnford, secretary of the Charity Commissioners, Mr. Durnford stated with reference to the scheme that the general scope and purpose of the proposals therein contained had the full support of the Charity Commissioners.

A protest against the scheme, signed by 14 Governors, has been sent in to the Commissioners, who intend to refer the matter of the scheme to one of their officers for local inquiry.

Management by a responsible executive, such as is proposed for Addenbrooke's, has become almost universal in the hospitals of this country; and we believe that it will conduce to the efficiency and economical administration of our hospital.

As it is most important that the Commissioners should be made acquainted with the views of the general body of Governors, we shall feel greatly obliged if you will kindly state on the enclosed postcard whether you are for, or against, the proposal to establish a responsible executive committee on the lines above suggested.

At the special General Court called to consider the matters referred to in this circular and held on the 26th ult., it was stated by the chairman, Mr. George Kett, that the poll had resulted in 192 votes being given in favour of the scheme and only 21 against it. In the result, after taking up a great deal of time by making speeches of inordinate length, the few and ancient Governors who are opposed to reform withdrew their opposition, and so there is at last good grounds for hope that Addenbrooke's Hospital may soon be granted a system of management on modern lines. Then, with the disappearance of the old bad system and its supporters, under which the finances of the hospital have gone from bad to worse, it is reasonable to hope that public confidence will be restored and adequate funds will then be provided.

\section{PRACTICAL DEPARTMENTS.}

\section{THE SERVIETTE QUESTION IN OPEN-AIR SANATORIA.}

By Charles Reinhardt, M.D.Brux., L.S.A.Lond.

EVERYONE who has experience of sanatorium life is familiar with the table-napkin question.

At many open-air institutions the patients are provided with Japanese paper serviettes, but these are as a rule satisfactory neither to the patients nor to the members of the staff. In theory they should be a great boon, for they are always clean and are destroyed by burning after being used once, but in practice there are objections.

Nine out of ten patients object to the sensation of applying the paper napkin to their mouths and the tenth does not like its smell, and nearly all would rather be deprived of serviettes altogether than be dependent upon the paper variety. Then they are so light and flimsy that the pleasant breezes which pervade the dining-halls of sanatoria are apt to waft them either off the table altogether or into a neighbour's plate; occasionally they fly out of the dining-room and hide themselves in the shrubs or mingle with the flower-beds. When neatly folded on the table before the meal commences

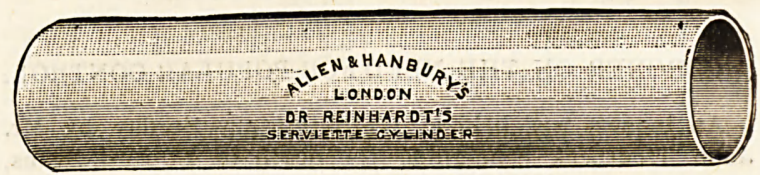

they look attractive if not positively appetising, but when clinging to the branches of a rose-tree, or reposing amongst a bed of pansies, they are not decorative.

There are objections to the use of the linen napkin in that being used for more than one meal and packed away in a drawer in the interval with only the protection of the napkin ring, an -undesirable contact between the serviettes of different patients is unavoidable. The phthisical patient who not only uses his table napkin in the ordinary manner, but instinctively raises it to his mouth when obliged to cough at table, cannot fail to infect it with tubercular bacilli; and since the aim of every sanatorium superintendent must be to achieve the most perfect possible condition of hygiene in his institution, he cannot afford to risk infection by serviette.

Various devices are employed at different sanatoria to prevent the contact of table napkins; some of them are not resthetically satisfactory. At one sanatorium in England washable linen bags are provided for each patient, and though they may answer their purpose they do not look attractive, which is a serious disadvantage, for the table appointments should be entirely unobjectionable in an institution which depends for its success largely upon the work done by the cook in the kitchen and by patients in the dining-room.

To meet the difficulty which ensued when I had to admit that the paper napkin, and the unenclosed linen serviette were unsatisfactory, I devised a serviette cylinder made of solid celluloid with smooth surfaces which is easily cleansed, 